\title{
Polanyi: Classical Moral Economist or Pioneer Cultural Political Economist?
}

\author{
Bob Jessop · Ngai-Ling Sum
}

(C) The Author(s) 2019

\begin{abstract}
This article evaluates Polanyi's work from two complementary theoretical perspectives: moral economy and cultural political economy. Polanyi's comparative historical analyses of substantive economies, their modes of distribution and the bases for their respective kinds of relative unity and stability, the rise of the market economy in and through its disembedding from more encompassing social relations, the social bases and motives for resistance to this disembedding, and its subsequent re-embedding in a market society are major theoretical and methodological contributions to the study of moral economies. Polanyi's work can also be explored for insights that anticipate the emerging post-disciplinary approach of cultural political economy, which combines critical semiotic analysis and the critique of political economy. More importantly, cultural political economy provides new theoretical and methodological tools for elaborating Polanyi's brilliant insights into moral economy.
\end{abstract}

Keywords Cultural political economy $\cdot$ Embeddedness $\cdot$ Market economy · Market society $\cdot$ Moral economy

\section{Polanyi: Klassischer Moralökonom oder Pionier als kulturpolitischer Ökonom?}

Zusammenfassung In diesem Beitrag werden Polanyis Arbeiten aus zwei komplementären theoretischen Perspektiven bewertet: moralische Ökonomie und kulturelle

B. Jessop $(\bowtie)$

Sociology, Bowland North, Lancaster University, Lancaster, LA1 4YN, UK

E-Mail: b.jessop@lancaster.ac.uk

N.-L. Sum

Politics, Philosophy, and Religion, County South, Lancaster University, Lancaster, LA1 4YQ, UK

E-Mail: n.sum@lancaster.ac.uk 
politische Ökonomie. Polanyis vergleichende historische Analysen der sachlich-materiellen (,substantive“) Ökonomie, ihrer Verteilungsweisen und der Grundlagen für die relative Einheit und Stabilität der unterschiedlichen Formen der sachlichmateriellen Ökonomie, des Aufstiegs der Marktwirtschaft durch ihre Entbettung aus umfassenderen sozialen Beziehungen, der sozialen Grundlagen und Motive für den Widerstand gegen diese Entbettung und die anschließende Neueinbettung in eine Marktgesellschaft können als wichtige theoretische und methodologische Beiträge zur Erforschung von moralischen Ökonomien betrachtet werden. Man kann seine Arbeit auch als fruchtbare Einsichten lesen, die den aufkommenden postdisziplinären Ansatz der kulturellen politischen Ökonomie antizipieren, welcher eine kritische semiotische Analyse und die Kritik der politischen Ökonomie verbindet. Noch wichtiger ist jedoch, dass die kulturelle politische Ökonomie neue theoretische Begriffe und methodologische Werkzeuge bietet, um Polanyis brillante Einblicke in die moralische Ökonomie weiterzuentwickeln.

Schlüsselwörter Kulturelle politische Ökonomie $\cdot$ Einbettung · Marktwirtschaft · Marktgesellschaft · Moralische Ökonomie

Karl Polanyi's work has been interpreted, contextualized, and appropriated from many, often contrasting, sometimes antithetical, perspectives. We will employ two: moral economy and cultural political economy. Briefly, moral economy has more scientific and more normative variants, reflecting the primacy of scientific or moral arguments. ${ }^{1}$ The former variant examines how economic activities and institutions are structured and guided by norms concerning rights and responsibilities; and the latter variant discusses how they should be structured and guided to promote thicker or thinner moral values. Polanyi's work is readily positioned within both versions. For example, he argued that: "[t]he true criticism of market society is not that it was based on economics - in a sense, every and any society must be based on it—but that its economy was based on self-interest" (Polanyi 2001, p. 257). Self-interest need not take the extreme form of Ayn Rand's objectivist philosophy, which regards the selfish pursuit of rational self-interest as having a high moral purpose (Rand and Branden 1964; for a critique, see Burns 2009). ${ }^{2}$ But pursuit of self-interest can occur at the expense of shared interests and produce negative externalities that ravage society when linked to the "utterly materialistic" creed that "all human problems could be resolved given an unlimited number of material commodities" (Polanyi 2001, p. 42). Polanyi counterposes this materialistic economy to the preindustrial epoch, when economic activities were embedded in familial, age-group, totemic, political, or religious relations and when commitments to reciprocity and

\footnotetext{
1 For anthropological, Aristotelian, critical rational choice, and ethico-political perspectives on moral economy, see, respectively: Scott (1976), Sayer (2014), Bowles (2016), and Rogan (2017).

2 Polanyi anticipated this selfish rationale in his critical comment on Mandeville's Fable of the Bees, which praises "vanity and envy, vice and waste" (Polanyi 2001, p. 114); and he condemned Bentham's selfinterested utilitarian proposal to exploit paupers and inhuman naturalism in classical political economy (Polanyi 2001, pp. 111-113, 128-133).
} 
redistribution ensured individual, household and societal subsistence, short of disasters that overwhelmed the whole community (Polanyi 1957a, pp. 68-71, 81, 90, 2001, pp. 48-51). In contrast to the nineteenth century "marketing view of society" that assumes the omnipresence of separate economic institutions, "the characteristic of human societies is precisely the absence of such separate and distinct-economic institutions. That the economic system is 'embedded' in the social relations means precisely this" (Polanyi 2001, p. 101). This critique of market society on moral grounds helps explain the oft-renewed engagement with Polanyi's work, regardless of how specific aspects of his comparative historical analyses have been judged over time. Thus, we begin by putting Polanyi in his place in moral economy and draw out the normative as well as scientific aspects of analyses of his substantive economic activities and institutions and the moral harm that unregulated market forces can do to humankind and nature.

Cultural political economy (hereafter, $\mathrm{CPE}$ ) is an emerging scientific discipline that combines critical semiotic analysis with critical political economy to study the contingent evolution of forms of economic organization and political domination. In our version, it also seeks to critique domination (Herrschaftskritik) and ideology (Ideologiekritik). Few, if any, would claim that Polanyi employed even implicitly critical semiotic analysis. But his anthropological and historical analyses did explore the role of language in the development of civilization, the genealogy of a specialized economic vocabulary, changing social and economic imaginaries (our term), different economic projects, and the language and motives of mobilized in justifying and resisting the market economy. In this sense, although he did not employ the specialized tools of semiotic analysis (originating with Ferdinand de Saussure's semiology and Charles Peirce's semiotics and much refined since then for mainstream and critical purposes), ${ }^{3}$ he can be regarded as a pre-theoretical critical discourse analyst. And he certainly linked this to his condemnation of industrial civilization, the effects of attempting to create self-regulating markets in the three fictitious commodities of land, money, and labour. Thus, we also consider how Polanyi's arguments can be mined to advance CPE's heuristic and explanatory power and, conversely, how his acknowledged contributions to moral economy could be made more productive by drawing on CPE concepts and methods.

\section{Classical moral economist}

Moral economy does not restrict its object of inquiry to particular epochs, modes of distribution or production, or social groups (Booth 1994; Sayer 2007; Götz 2015; Palomera and Vetta 2016). Nor is it to be confused with the "economy of morals" in the Foucauldian sense of the production and circulation of morals (see the critique in Fassin 2009). Rather, it seeks to identify the ethical and moral foundations of economic orders, varieties of moral economy across time and space, the motives and values of agents engaged in (or refraining from) economic activities, and the effects of economic institutions and conduct on the wider social order. In gen-

\footnotetext{
3 See de Saussure (1983) and Peirce (1992). On more recent developments, see Sum and Jessop (2013).
} 
eral, moral economy explores the genesis, variation, selection, and consolidation of specific economic imaginaries and their ethical and moral underpinnings. This highly mediated (and increasingly mediatized) process involves struggles for intellectual and moral leadership, efforts to justify or critique economic arrangements, and use of different discursive strategies and tactics to this end. Moral imaginaries may give more weight to deontological (value-rational or wertrational) principles or consequentialist principles that relate various means and ends in a more pluralistic, zweckrational manner (Polanyi 1957b, pp. 239-240, 245-247). Polanyi also distinguished ideal from material interests, their differential articulation, and condemned the materialism of market economies (Polanyi 1947, pp. 97, 101). Normative moral economy also explores how and how far specific economic arrangements facilitate, thwart, or undermine a preferred thick or thin moral order, ranging from the right to food and shelter to the conditions for human flourishing.

Chris Hann described Polanyi as "the most sophisticated theoretician of the moral economy writ large" (Hann 2010, p. 196). While overstated, this is a good entrypoint into Polanyi's work. He developed a comparative, historical institutionalist account of different moral economies that praised Aristotle for his pioneering and still productive insights into this field (Polanyi 1957a, 2001, pp. 56-57, 119) and was also inspired by Robert Owen and Christian Socialism (e.g., Baum 1996). His approach has strong affinities to that of classical moral economists such as Adam Smith, hence our description.

The crucial theoretical underpinning of Polanyi's approach is an analytical distinction between substantive and formal economics. This is linked to his historical distinction between non-market and market economies and to his suggestion that, while it is anachronistic to talk of "economic motives" in non-market economies, they emerge and become dominant in market economies at the expense of wider "social motives", such as honour, pride, solidarity, civil obligation, moral duty or simply a sense of common decency (Polanyi 1947, pp. 98, 101, 2001, p. 31). In non-market societies, "[t]he human economy [...] is embedded and enmeshed in institutions, economic and noneconomic. The inclusion of the noneconomic is vital. For religion or government may be as important for the structure and functioning of the economy as monetary institutions or the availability of tools and machines" (Polanyi 1957b, p. 250, cf. 2001, p. 48). This entails that the application of formal economics is wholly inappropriate to non-market economies ${ }^{4}$. Because there is no price-making mechanism, the distribution of want-satisfying material resources of varied provenance is governed by non-market moral codes and organizational principles. However, in market economies, everything eventually acquires a market price and enters exchange relations. Exchange is the dominant mechanism of distribution and the interaction of supply and demand distributes goods and services as commodities. Thus, market economies are systems

controlled, regulated, and directed by markets alone; order in the production and distribution of goods is entrusted to this self-regulating mechanism. [...]

\footnotetext{
4 Polanyi has been criticized for exaggerating the differences between non-market and market economies; on specific monies and all-purpose money, see Melitz (1970); and, on the Mesopotamian and Ancient Greek cases, Dale (2016, pp. 161-201).
} 
Self-regulation implies that all production is for sale on the market and that all incomes derive from such sales. Accordingly, there are markets for all elements of industry, not only for goods (always including services) but also for labor, land, and money, their prices being called respectively commodity prices, wages, rent, and interest (Polanyi 2001, pp. 71-72, cf. 1947, p. 98, where Polanyi adds that profit is the reward to the successful entrepreneur).

In short, market forces define what will count as exchange-values, mediate their exchange, and reproduce market relations as commodities are exchanged for money.

On this basis, Polanyi distinguished a substantive, transhistorical definition of economics as want-satisfying behaviour and a formal, historically specific definition of economics as rational, economizing behaviour. The economy, in its substantive sense, is "an instituted process of interaction between man and his environment, which results in a continuous supply of want-satisfying material means" (Polanyi 1957b, p. 248). This covers non-market and market economies. Formal economics, however, does not recognize the distinction. It thereby commits the "economistic fallacy" in seeing all economic conduct as formally rational and economizing and assimilates the properties of other non-capitalist economies to those of market economies (Polanyi 1977).

The study of how economies are instituted should start, Polanyi suggests, from how the economy acquires unity and stability. Thus, in his history of trade and markets as well as his economic anthropology, he argues that societal (institutional) conditions sustain the (circular) interdependence of economic movements and ensure the "recurrence" of its parts (i.e., their continued reproduction)—without which neither the unity nor stability of the (instituted) economic process is possible. He focused here on basic structural principles-householding, reciprocity, redistribution, or exchange - that institute the economic process and vest it with institutional unity and stability. This

produces a structure with a definite function in society; it shifts the place of the process in society, thus adding significance to its history; it centers interest on values, motives and policy. Unity and stability, structure and function, history and policy spell out operationally the content of our assertion that the human economy is an instituted process (Polanyi 1957b, pp. 249-250, italics added).

Given his interest in both market and non-market economies and his critique of the economistic fallacy, Polanyi focused on principles of distribution of "want-satisfying material means" regardless of how their production is organized. For, while it is hard analytically to disentangle production from other social activities in non-market economies, it is usually possible to identify the operational principles governing resource distribution. Polanyi identified four main principles of distribution, each of which has its own moral principles and institutional supports: (1) householding based on production to satisfy the needs of a largely self-sufficient unit such as an extended family or kin group, settlement, or manor; (2) reciprocity among similarly arranged or organized groupings (e.g., segmentary kinship groups); (3) redistribution via an allocative centre linked to a political regime (Polanyi 1977, pp. 34-47; 1957b, pp. 250-256, 2001, pp. 51-52). The corresponding institutional principles 
were autarchy, symmetry, and centricity (Polanyi 2001, pp. 51-60). In each, "institutional patterns and principles of behaviour are mutually adjusted" (Polanyi 2001, p. 51, cf. pp. 70-71). To these historically compossible arrangements, Polanyi contrasted: (4) the anarchy of exchange as mediated through a catallaxy of trade, money, and price-making markets in a disembedded and potentially self-regulating economy (Polanyi 1957b, pp. 257, 266-270, 2001, pp. 60, 71-75). In this case, mutual adjustment means that "society must be shaped in such a manner as to allow that system to function according to its own laws. [...] [For] a market economy can function only in a market society" (Polanyi 2001, p. 60).

Commenting on these four principles, Polanyi added that trade need not be organized through monetary exchange: it can be organized as a reciprocal gift relationship or administered from above in redistributive systems (Polanyi 1957b, pp. 262-263, 2001, pp. 59-70). As well as its role in historical and comparative analysis, this typology also enables Polanyi to show that monetary gain is not vital to distribution and trade. This is a further contribution to undermining the "economistic fallacy" that rests on a transhistorical model that treats market exchange as primordial and universal. ${ }^{5}$

Polanyi put this as follows:

Instead of economy being embedded in social relations, social relations are embedded in the economic system. The vital importance of the economic factor to the existence of society precludes any other result. For once the economic system is organized in separate institutions, based on specific motives and conferring a special status, society must be shaped in such a manner as to allow that system to function according to its own laws. This is the meaning of the familiar assertion that a market economy can function only in a market society (Polanyi 1957b, p. 57, italics added).

This statement is a major corrective to one-sided readings of Polanyi that focus only on the disembedding of the capitalist economy from pre-capitalist social arrangements and institutions. For it also highlights the process whereby a newly differentiated market economy is re-embedded into an emerging market society. It is unclear at this stage in his argument whether this refers to the apogee of selfregulating markets in the 19th century as they were disembedded from their earlier institutional frameworks, thereby enabling laissez-faire principles to be instituted on a society-wide basis with the result that "the running of society is an adjunct to the market" (Polanyi 2001, p. 60); or it refers to the process whereby the society that is being forced to adapt and reorganize in this way starts to "fight back" by demanding new social institutions that can constrain market forces and compensate for market failures.

\footnotetext{
${ }^{5}$ For a counter-argument that Polanyi's ideas on self-regulating markets incorporate neo-classical ideas, see Gemici (2015) and Mirowski (2018).
} 


\section{The "double movement" of capitalist development}

This ambiguity in the denotation and connotations of the "double movement" is captured in Polanyi's "double movement". He suggested that this

can be personified as the action of two organizing principles in society, each of them setting itself specific institutional aims, having the support of definite social forces and using its own distinctive methods. The one was the principle of economic liberalism, aiming at the establishment of a self-regulating market, relying on the support of the trading classes, and using largely laissez-faire and free trade as its methods; the other was the principle of social protection aiming at the conservation of man and nature as well as productive organization, relying on the varying support of those most immediately affected by the deleterious action of the market—primarily, but not exclusively, the working and the landed classes - and using protective legislation, restrictive associations, and other instruments of intervention as its methods (Polanyi 2001, pp. 138-139).

These two principles are not purely economic but embody specific normative principles and values. First, the liberal principle is premised on hunger and fear of hunger for those who possess only labour power and unbridled pursuit of gain, or the prospect of it, on the part of those who own or control land and money (Polanyi 1947, p. 98). However, ideologically, as Marx noted, in the labour market and in commercial exchange, this creates the appearance of a "very Eden of the innate rights of man [w] here alone rule Freedom, Equality, Property" (Marx 1996, p. 186). In contrast, the principle of social protection addresses actual asymmetries in the labour process, the negative externalities of unregulated markets, other forms of market failure, and the need to secure daily, lifetime, and intergenerational social reproduction that cannot be fully delivered, let alone guaranteed, by self-regulating markets in labour and land. Indeed, Polanyi argues:

Robbed of the protective covering of cultural institutions, human beings would
perish from the effects of social exposure; they would die as the victims of
acute social dislocation through vice, perversion, crime, and starvation. Nature
would be reduced to its elements, neighborhoods and landscapes defiled, rivers
polluted, military safety jeopardized, the power to produce food and raw mate-
rials destroyed. Finally, the market administration of purchasing power would
periodically liquidate business enterprise, for shortages and surfeits of money
would prove as disastrous to business as floods and droughts in primitive soci-
ety (Polanyi 2001, p. 76).

Second, although the countermovement was essential to protect society from the annihilating effects of the commodification of land and labour, "in the last analysis it was incompatible with the self-regulation of the market, and thus with the market system itself" (Polanyi 2001, p. 136). Pushed too far, it would undermine the market economy, which, as a self-regulating system, reacts unpredictably to outside intervention. In addition, market winners also resist such intervention. In an astute comment bearing directly on this dialectic, Claus Offe once remarked: "while capitalism cannot co-exist with, neither can it exist without, the welfare state" (Offe 
1984, p. 153). This also holds for other forms of social protection. Hence, third, the diverse interventions of "society" (notably, but not only, made by the state in response to demands coming from political and civil society) were limited to "checking the action of the market in respect to the factors of production, labor, and land" (Polanyi 2001, p. 136). We revisit this topic below.

\section{A precursor of cultural political economy?}

CPE combines critical semiotic analysis and critical political economy. The first studies the role of sense- and meaning-making in reducing complexity so that actors can "go on" in the world. The contrasting ways in which fascism and (Christian) socialism reduced the complexity of industrial civilization and its discontents, was a major theme in the concluding chapter of The Great Transformation (Polanyi 2001, pp. 244-248, 265-268). It also animated Polanyi's concern to work out the institutional and moral or religious conditions for human freedom in a society that had become irredeemably complex (Polanyi 2001, pp. 180, 262-266, 269). Complementing critical semiotic analysis is critical political economy. Here CPE analyses the structuring principles that give an always relative (and provisional) unity and stability to a given social formation such that "not everything that is possible is compossible". This is anticipated in Polanyi's strong interest in the sources of the relative unity and stability of specific substantive economies. It is illustrated in his comment on "the mutual incompatibility of institutions like the wage system and the 'right to live,' or, in other words, [...] the impossibility of a functioning capitalistic order as long as wages were from public funds" (Polanyi 2001, p. 86); and, likewise, that "the self-protection of society for which he [Owen] was calling would prove incompatible with the functioning of the economic system itself" (Polanyi 2001, p. 135).

\subsection{A Critical Semiotic Institutionalism}

CPE applies semiotic analysis to instituted economic and political relations and their social embedding in one or more wider social formations. While Polanyi did not employ a specialist semiotic vocabulary or use specialist techniques to analyse patterns of meaning or structures of feeling, he insisted on the crucial roles of "household truths", "elementary truths", "common sense attitudes", traditional mindsets, ${ }^{6}$ implicit theories, socially instituted mental models, competing utopias, and social (later, also explicitly economic) imaginaries in shaping predispositions, defining social obligations, framing social projects, and inspiring action. He analysed them in their historical context, considered specific creeds or worldviews (and many

\footnotetext{
${ }^{6}$ For example, the Speenhamland system worked because "this was an essentially precapitalistic age, when the common people were still traditionally minded, and far from being directed in their behavior by monetary motives alone" (Polanyi 2001, p. 85).
} 
"-isms") 7 in terms of their differential articulation of several imaginaries, provided accounts of their structural conditions of existence (e.g., in his comments on the organic link between machinofacture and the rise of the value-laden discipline of "political economy"), ${ }^{8}$ offered periodizations of their development that were attuned to uneven selection and retention of some elements over others, and considered the performative effects of different belief systems in consolidating or resisting specific institutional arrangements. ${ }^{9}$ Much of this involved implicit critiques of ideology but Polanyi was also quite open about his intentions in other contexts as he revealed his "sacred hatred" of the market economy and his hostility to the "economistic fallacy" in the academy and real world.

The most telling example in The Great Transformation is Polanyi's critique of "the faith of the age", "satanistic creed", or "one and only tenet common to men of all nations and all classes, religious denominations, and social philosophies" (Polanyi 2001, p. 26) that comprised the fetishistic belief, which united capitalists and socialists alike, in the value and virtues of the Gold Standard (p. 26). Polanyi also explores the performative effects of this liberal economic imaginary on policies, politics, polities, economic development, and social antagonisms, both before and after its collapse (Polanyi 2001, pp. 21-30). Of course, Polanyi concedes that the "world revolution" triggered by "the snapping of the golden thread" (Polanyi 2001 , p. 29) cannot be attributed solely to the ill-judged "faith of the age". It had crucial ideational bases in the wider system of political economy that sought to fit the "amazing regularities and stunning contradictions [of self-regulating markets] [...] into the scheme of philosophy and theology" and reconcile their selfevident constraints and destructive implications with the moral principles of harmony and pursuit of freedom (Polanyi 2001, pp. 31, 88-89). In addition, laissezfaire was associated with "social instrumentalities" (Polanyi 2001, p. 8) such as the other three institutional pillars of the self-regulating market economy and the role of haute finance in governing the relations among all four pillars in its capacity as a decentred coordinating network of banks that also worked with governments to maintain peace (Polanyi 2001, pp. 10-11). Cross-class social alliances drawing on quite diverse logics of justification also played their role. And the ideological blinkers of the advocates of laissez-faire from the 1820s onwards leading to neglect of accumulating tensions and crisis-tendencies from self-regulating labour markets, the gold standard, and free trade (Polanyi 2001, pp. 21, 141).

When crises did erupt, Polanyi also explored the contested efforts of different social forces to connect crisis symptoms to underlying causes (Polanyi 2001, pp. 94-95, 110-111). This is the field of symptomatology (see Jessop 2015). It matters because, as Polanyi realized, how crises come to be defined within hegemonic

\footnotetext{
7 Polanyi commented on constitutionalism, cosmopolitanism, equalitarianism, fascism, humanitarianism, individualism, internationalism, interventionism, liberalism, mercantilism, nationalism, naturalism, Owenism, pacifism, paternalism, patriotism, philosophical anarchism, protectionism, "Tory socialism", socialism, syndicalism, utilitarianism, and zoological determinism (Polanyi 2001, passim).

8 For example, Polanyi (2001, pp. 42-43).

9 See his analysis of the performativity of Adam Smith's economic imaginary and its diffusion into many disciplines (Polanyi 2001, pp. 45-46).
} 
or dominant discourses and how counter-hegemonic discourses contest them shape crisis-management. This is illustrated in his analysis of diverse responses to the collapse of the Gold Standard in major capitalist economies and his more general account of the double movement.

\subsection{A critical political economist}

Turning to CPE's critical political economy moment, Polanyi's comparative historical focus on substantive economies is innovative in four ways. First, analysing them through the lens of distribution produces important new insights into earlier periods without losing sight of the historical specificity of the capitalist mode of production. For, in Polanyian terms, it is the dominance of the exchange principle tied to the generalization of the commodity form to all the inputs into production that separates capitalism from pre- or non-capitalist social formations. Second, by highlighting the fictitious character of land, labour, and money as commodities, i.e., their treatment as if they were commodities when they are not produced for sale but do have a price, he provides grounding for a normative moral economy and a critical scientific analysis of capitalism. This approach can also be generalized to knowledge as a fourth fictitious commodity (cf. Jessop 2007). Third, his inquiry into the bases of the unity and stability of specific substantive economic arrangements has parallels with Gramsci's analysis of the "historical bloc"10 in capitalism and with French régulationist research on accumulation regimes, modes of regulation, and societal paradigms (Gramsci 1971; Boyer 1990). But his analysis has a far broader historical sweep and, importantly, has an adequate conceptual schema to deal with pre-capitalist societies.

Fourth, his fourfold typology of autarky, reciprocity, redistribution, and exchange as organizational principles and their differential articulation in particular substantive economies has affinities with distinctions in governance theory between solidarity, networks, hierarchy, and markets, the scope for hybridization, and issues of metagovernance. A well-developed example is, once more, Polanyi's account of haute finance in the golden age of laissez-faire as a crucial mode of what nowadays would be called metagovernance. Haute finance was "the main link between the political and the economic organization of the world in this period [...] a permanent agency of the most elastic kind [...] the nucleus of one of the most complex institutions the history of man has produced" (Polanyi 2001, pp. 10-11). It rested not only on an interpersonal network with diasporic as well as national dimensions but also depended on a complex web of interorganizational relations that reconciled the rival logics of the economic, political, and military systems on both national and international levels (Polanyi 2001, pp. 210-217). It would be a major contribution to international political economy to develop a more formalized, systematic analysis of this de-centred parallel power network that also worked with governments and to compare this with analogous agents and mechanisms of metagovernance economy at other times and/or elsewhere.

10 For Gramsci, an "historical bloc" reflects "the necessary reciprocity between structure and superstructure" (Gramsci 1971, p. 366). 


\subsection{The potential of CPE}

We now consider how CPE can be used to identify and compensate two weak points in Polanyi's theoretical work: embeddedness and resistance. First, he had a pretheoretical ${ }^{11}$ notion of embeddedness, dis- and re-embedding, especially in The Great Transformation, but clarity on these processes is critical to fully understanding the potential of his work in this regard. The sequence of embedding, disembedding, and re-embedding provides a powerful heuristic that could be enhanced through more detailed analysis of the institutional arrangements to which they relate and by considering whether this is a "fractal" process, i. e., one that occurs in similar ways at different scales and over different time horizons. There are strong hints of this in The Great Transformation and The Livelihood of Man. Developing these hints would help disinterested researchers and concerned citizens to understand how neoliberalization can recuperate from shocks through its amazing capacities hitherto for reinvention across different spatio-temporal scales and horizons of action-although it may finally be running out of road for this as the double movement takes populist rightwing forms.

Second, an enduring appeal of Polanyian moral economy is its emphasis on how "society" fights back against the damaging economic, social, and environmental consequences of the growth of self-regulating markets in labour, money, and land. There are two main problems here: lack of clarity about the range of ways in which the logic of the market can colonize the whole field of social relations-ways which go beyond the process of fictitious commodification; and an ill-specified and reified notion of "society" as a source of resistance. ${ }^{12}$ The cultural political economist Bob Jessop, drawing on four odd theoretical bedfellows (Marx, Luhmann, Polanyi, Gramsci), identified four mechanisms of capitalist societalization with different sites and modes of resistance. The first, Marxian, mechanism involves extending the capital-labour relation and the primacy of self-valorization into areas of social life where they were previously absent. The second, Luhmannian, mechanism is the superimposition of profitability as a secondary code in social fields where another code is primary (e. g., science, law, politics, and education), modifying their calculations and practices to the detriment of their original purposes. Third, as emphasized by Polanyi, the combination of fictitious commodification and the profit-oriented, market-mediated logic of capital accumulation can cause more problems for other systems, the lifeworld, and the natural environment than they can cause for it. ${ }^{13}$ And, fourth, there are attempts to inflect state projects and hegemonic visions with the goals and values of a mythical, magical, mysterious market fundamentalist utopia (Jessop 2002, pp. 22-30).

\footnotetext{
${ }^{11}$ Olofsson shows that Polanyi used various words for embeddedness in his magnum opus that are "either linguistic varieties of the same concept (i.e., embeddedness) or that take up partly different specialized meanings of the general concept" (Olofsson 1995, p. 86). See also Gemici (2008). Also relevant is Polanyi's distinction between the substantive (embedded) and formal (disembedded) concepts of the economy (Polanyi 1977).

${ }^{12}$ For a systematic critique of Polanyi's account of society, see Hodgson (2017).

13 Jessop linked this third moment to the growing "ecological dominance" of the logic of capital (Jessop 2002, pp. 26-29); but Polanyi clearly anticipated this using other language.
} 
There are four corresponding forms of resistance. First, there are class struggles proper around the capital-labour relation, fictitious commodification, and their extraeconomic conditions of existence. Polanyi recognized the role of rival class interests in this regard, insisting that these are not just economic but extend into other social fields, and arguing that the reaction of classes to unregulated market forces is one way in which "society" resists its destruction by the market (Polanyi 2001, p. 132). But he also highlighted non-class bases of spontaneous resistance to the logic of the market (Polanyi 2001, pp. 159-161). In this respect, he identified the role of "professional persons" in resisting the logic of marketization, which could be related to the second mechanism. Regarding the third mechanism, in a passage that suggests the potential of his approach to analyse the roots of trans-class alliances in dispersed non-class identities, Polanyi records the heterogeneity of the social categories who resist the wider effects of commodification and marketization:

While monetary interests are necessarily voiced solely by the persons to whom they pertain, other interests have a wider constituency. They affect individuals in innumerable ways as neighbors, professional persons, consumers, pedestrians, commuters, sportsmen, hikers, gardeners, patients, mothers, or lovers - and are accordingly capable of representation by almost any type of territorial or functional association such as churches, townships, fraternal lodges, clubs, trade unions, or, most commonly, political parties based on broad principles of adherence (Polanyi 2001, p. 162).

Finally, given his eye for historical detail, it is unsurprising that Polanyi also recognises forms of resistance to the eventual consolidation of self-regulating markets in a fully consolidated market society. For him, this is expressed in the polar principles of liberalism and social protection, around which different hegemonic, sub-hegemonic, and counter-hegemonic struggles occur over the entrenchment or rolling back of marketization, seeking to shape and mobilize "common sense" for or against extending the logic of capital accumulation as the desirable and/or necessary condition for accomplishing other social goals. This is reflected in the competing economic and political programmes and ethico-political visions into which economic liberalism is articulated and the range of counter-hegemonic projects developed to resist the onward march of liberalism. For, if society's fightback is to move beyond dispersed, disorganized, and mutually contradictory struggles, attention must be paid to how, and how far, 'society' acquires a relative unity and cohesion in resisting capital's unhampered logic. That this is not guaranteed is illustrated by Polanyi's contrast between the responses of rural and urban forces, reflecting their different traditions and aspirations: "the landed classes might attempt a return to a military or feudal regime of paternalism, while the factory workers would see the need for the establishment of a cooperative commonwealth of labor" (Polanyi 2001, p. 162). ${ }^{14}$

As Polanyi argues, the reaction of society to the destructive impact of liberal market forces is not conducted merely in terms of sectional interests but in the name of the general interest of society as a whole. This is where the role of specific

14 We owe this illustration to an anonymous reviewer. 
economic, political, and social projects, of hegemonic visions, and of associated strategic capacities becomes crucial. Indeed, as Polanyi well knew, it makes a world of difference whether this resistance is conducted under the dominance of fascism, ${ }^{15}$ social democracy, corporate liberalism à la New Deal, or a communist regime. And he also saw a maximally decentralized socialism (his preferred alternative, which would overcome the institutional separation of the economic and the political) as 'essentially, the tendency inherent in an industrial civilization to transcend the selfregulating market by consciously subordinating it to a democratic society' (Polanyi 2001, p. 242).

\section{Conclusions}

Polanyi developed a powerful, if pre-theoretical and sometimes thin, critical moral economy. This animated his "sacred hatred" towards liberalism in the name of humanist values and, even more strongly, his critique of fascism as a response to the failures of liberalism. His scientific study of moral economy had its own genealogy, vocabulary, and logic and enabled him to develop powerful insights in substantive economies that differ from those generated within political economy and cultural political economy. Regarding CPE, Polanyi was also deeply interested in the changing semantics of substantive economies, their constitutive role in ordering specific social formations, and the evolution of organic economic and social imaginaries, and the semantics of economic activities, devices and institutions. But he lacked the theoretical interests and conceptual vocabulary to develop these points along the lines of CPE, which has benefitted from a further 60-70 years' research in these fields. The second key aspect of CPE is its interest in structuration. Here Polanyi's account of the principles and practices that secured the relative unity and stability of different regimes of material provisioning and, especially, of the limits on the compossibility of different economic and extra-economic arrangements, suggests that he could be described as a proto-regulation theorist. In short, while Polanyi is best situated in relation to classical moral economy, his work can also be mined to advantage for insights relevant to critical semiotic analysis and critical political economy.

We suggest that combining the three approaches adds intellectual value to each. For example, Polanyi was unaware of the extent to which Marx had already anticipated his analysis of the three fictitious commodities of labour-power, money (including credit and money as capital), and land (see Jessop 2019) and he did not build on Marx's incisive analyses of the contradictions and crisis-tendencies in the capital relation, inclining on many occasions to be dismissive of its underlying theoretical assumptions. Likewise, although he showed the limits of self-regulating markets in coordinating economics, politics, and civil society in liberal bourgeois civilization,

\footnotetext{
15 Polanyi interpreted fascism as a totalitarian attempt to subordinate an entire society to the logic of the market in the interests of the proprietors; he analysed its anti-universalist ideology of "blood and race", neo-feudal economic structures, and political matrix within which it emerged occurred (see Maucourant 2000).
} 
he presents these insights in an ad hoc, eclectic manner. Conversely, Polanyi recognized empirically that "society's" fightback against self-regulating markets is neither directed against market forces (or capitalism) as such nor is it a reaction of 'society' as such and is by no means reducible to class struggles, however wide-ranging. But he lacked the theoretical vocabulary to analyse this and could merely cite different examples. The "double movement" involved a complex series of reactions at many different points in social space to specific conflicts, crisis-tendencies, and contradictions associated with the unregulated extension of market forces. A more systematic analysis of the motives, movers, and mechanisms of the "double movement" could be facilitated through CPE.

Acknowledgements Bob Jessop acknowledges financial support from the Economic and Social Research Council for his contributions to this article grant under the WISERD Civil Society programme at Cardiff University [Award: ES/L009099/1]. Both authors also thank two anonymous referees for their helpful comments.

Open Access This article is distributed under the terms of the Creative Commons Attribution 4.0 International License (http://creativecommons.org/licenses/by/4.0/), which permits unrestricted use, distribution, and reproduction in any medium, provided you give appropriate credit to the original author(s) and the source, provide a link to the Creative Commons license, and indicate if changes were made.

\section{References}

Baum, Gregory. 1996. Karl Polanyi on ethics and economics. Montréal: McGill-Queen's University Press. Booth, William J. 1994. On the idea of the moral economy. American Political Science Review 88(3):653667. https://doi.org/10.2307/2944801.

Bowles, Samuel. 2016. The moral economy: Why good incentives are no substitute for good citizens. New Haven: Yale University Press.

Boyer, Robert. 1990. The regulation school. A critical introduction. New York: Columbia University Press.

Burns, Jennifer. 2009. Goddess of the market: Ayn Rand and the American right. New York: Oxford University Press.

Dale, Gareth. 2016. Reconstructing Karl Polanyi. Excavation and critique. London: Pluto.

Fassin, Didier. 2009. Les économies morales revisitées. Annales. Histoire, sciences sociales 64(6):12371266.

Gemici, Kurtuluş. 2008. Karl Polanyi and the antinomies of embeddedness. Socio-Economic Review 6(1):5-33. https://doi.org/10.1093/ser/mw1034.

Gemici, Kurtuluş. 2015. The neoclassical origins of Polanyi's self-regulating market. Sociological Theory 33(2):125-147.

Götz, Norbert. 2015. 'Moral economy': Its conceptual history and analytical prospects. Journal of Global Ethics 11:147-162.

Gramsci, Antonio. 1971. Selections from the prison notebooks. London: Lawrence \& Wishart.

Hann, Chris. 2010. Moral economy. In The human economy: A citizens' guide, ed. Keith Hart, Jean-Louis Laville, and Antonio D. Cattani, 187-198. Cambridge: Polity.

Hodgson, Geoffrey M. 2017. Karl Polanyi on economy and society: A critical analysis of core concepts. Review of Social Economy 75(1):1-25.

Jessop, Bob. 2002. The future of the capitalist state. Cambridge: Polity.

Jessop, Bob. 2007. Knowledge as a fictitious commodity: Insights and limits of a Polanyian analysis. In Reading Karl Polanyi for the 21st century, ed. Ayşe Buğra, Kaan Ağartan, 115-134. Basingstoke: Palgrave.

Jessop, Bob. 2015. The symptomatology of crises: Reading crises and learning from them. Some critical realist reflections. Journal of Critical Realism 14(3):238-271.

Jessop, Bob. 2019. Money and credit as fictitious commodities, financialisation, and contemporary financial crises. In Great transformations? Capitalism after Polanyi, ed. Roland Atzmüller, et al. Cheltenham: Edward Elgar.

Marx, Karl. 1996. The process of production of capital. Capital: A critique of political economy, Vol. I. London: Lawrence \& Wishart. 
Maucourant, Jérôme. 2000. Polanyi, lecteur du Marx. Actuel Marx 27:133-151.

Melitz, Jacques. 1970. The Polanyi school of anthropology on money: An economist's view. American Anthropologist 72(5):1020-1040.

Mirowski, Philip. 2018. Polanyi vs Hayek? Globalizations 15(7):849-910.

Offe, Claus. 1984. Contradictions of the welfare state. London: Hutchinson.

Olofsson, Gunnar. 1995. Embeddedness and integration: An essay on Karl Polanyi's "The Great Transformation". In Social integration and marginalization, ed. Niels Mortensen, 72-113. Frederiksberg: Samfundslitteratur.

Palomera, Jaime, and Theodora Vetta. 2016. Moral economy: Rethinking a radical concept. Anthropological Theory 16:413-432.

Peirce, Charles S. 1992. The Essential Peirce: Selected philosophical writings (1867-1893). Bloomington: Indiana University Press.

Polanyi, Karl. 1947. On belief in economic determinism. Sociological Review 37(1):96-102.

Polanyi, Karl. 1957a. Aristotle discovers the economy. In Trade and market in the early empires, ed. Karl Polanyi, Conrad M. Arensberg, and Harry W. Pearson, 64-94. Glencoe: Free Press.

Polanyi, Karl. 1957b. The economy as instituted process. In Trade and market in the early empires, ed. Karl Polanyi, Conrad M. Arensberg, and Harry W. Pearson, 243-269. Glencoe: Free Press.

Polanyi, Karl. 1977. The livelihood of man. New York: Academic Press.

Polanyi, Karl. 2001. The great transformation: The political and economic origins of our time, 2nd paperback edition edn., Boston: Beacon Press.

Rand, Ayn, and Nathaniel Branden. 1964. The virtue of selfishness: A new concept of egoism. New York: New American Library.

Rogan, Tim. 2017. The moral economists: RH Tawney, Karl Polanyi, EP Thompson, and the critique of capitalism. Princeton: Princeton University Press.

de Saussure, Ferdinand. 1983. Course in general linguistics. La Salle: Open Court.

Sayer, Andrew. 2007. Moral economy as critique. New Political Economy 12:261-270.

Sayer, Andrew. 2014. Why we can't afford the rich. Bristol: Policy Press.

Scott, James C. 1976. The moral economy of the peasant: Rebellion and subsistence in Southeast Asia. New Haven: Yale University Press.

Sum, Ngai-Ling, and Bob Jessop. 2013. Towards a cultural political economy: Putting culture in its place in political economy. Cheltenham: Edward Elgar.

Bob Jessop is Distinguished Professor of Sociology at Lancaster University. His research covers critical state and governance theories, critical political economy, and neoliberalism. His most recent book is The State: Past, Present, Future (2015) and he is now writing Civil Society between Self-Emancipation and Self-Responsibilization (2019).

Ngai-Ling Sum is Reader in Cultural Political Economy at Lancaster University. Her research in cultural political economy draws on Marx, Gramsci, and Foucault. She co-authored Towards a Cultural Political Economy (Sum and Jessop 2013); and is now studying China's Belt-Road Initiative from critical geopolitical and subaltern perspectives. 